\title{
Effect of Seed Coating on Field Performance in Soybean (Glycine max. L)
}

\author{
R.K. Bony ${ }^{1 *}$, B. Rajeswari ${ }^{2}$, K. Jhansi ${ }^{1}$ and K. Keshavulu ${ }^{1}$ \\ ${ }^{1}$ Department of Seed Science and Technology, ${ }^{2}$ Department of Plant Pathology, ANGRAU, \\ Rajendranagar, Hyderabad-500030, Telangana, India \\ *Corresponding author
}

\section{A B S T R A C T}

Seed coating especially film-coating, is one such technique which has gained commercial importance owning to its practical utility as an effective delivery system for seed

Keywords

Soybean, Polymer,

Thiram,

Imidacloprid and $T$. viride.

Article Info

Accepted:

30 September 2017

Available Online:

10 November 2017 protectant and fortifying chemicals. Seeds of soybean cv. JS-335 were coated with polymer in combination with fungicide (thiram), insecticide (imidacloprid), bioagent (Trichoderma viride) and maintained untreated seeds (control). After seed treatment, the seeds were sown in the field with four replications adopting randomized block design in order to find out the effect of seed treatments on field emergence, plant biometrics viz., plant height, disease incidence at different stages (25 DAS, 50 DAS and 75 DAS), 100 seed weight, number of pods per plant and yield per hectare under field conditions were recorded. Yield per hectare was increased in seed treatments with polymer + thiram + imidacloprid $+T$. viride $\left(18.4 \mathrm{q} \mathrm{ha}^{-1}\right)$ or polymer + thiram + imidacloprid $\left(17.78 \mathrm{q} \mathrm{ha}^{-1}\right)$. The additional increase in yield per hectare over control were 5.2, 4.58, 3.24, 4.43, $1.68 \mathrm{q}$ in polymer + thitam + imidacloprid + T. viride (polymer@ $2 \mathrm{ml} \mathrm{kg}^{-1}$, thiram @ $3 \mathrm{ml} \mathrm{kg}^{-1}$, imidacloprid@2.5 ml kg-1 and T. viride@10 $\mathrm{g} \mathrm{kg}^{-1}$ ), polymer + thitam + imidacloprid, polymer + thitam, polymer + imidacloprid and polymer, respectively.

\section{Introduction}

Soybean [Glycine $\max (\mathrm{L}$.$) Merrill] is known$ as Golden bean and is commonly referred as 'miracle crop' or 'gold from soil'. It is playing an important role in overcoming the present shortage of edible oil and vegetable proteins in India as it contains $20 \%$ oil, $21 \%$ starch and $40 \%$ high quality protein. One of the major constraints in the endeavor of increasing productivity in soybean is its susceptibility to a large number of diseases caused by fungi, bacteria, viruses and nematodes. The annual losses due to soybean diseases are estimated to the tune of $12 \%$ of the total production in which fungal diseases alone can cause up to $6-8 \%$ damage. Besides this, the crop also suffers from a number of bacterial and viral diseases of economic significance. One of the major constraints in soybean production is the non-availability of quality seeds at the time of planting. Seed viability is a major factor in crop stand establishment and subsequent productivity in many parts of the world. Losses in seed quality occur during field weathering, harvesting and storage if they are exposed to high temperature and humidity. Seed coating materials were reported to improve the germination and increase the seedling emergence at changing soil moisture especially in the suboptimal range (Mucke, 1987). Seed coatings are extremely thin, which allows multiple layers on the seed with 
only a 1 to $10 \%$ increase in seed weight. Polymer coating improves plant stand and emergence of seeds, accurate application of the chemical reducing chemical wastage, helps to make room for including all required ingredients, protectants, nutrients, plant growth promoters, hydrophobic/hydrophilic substance, oxygen suppliers etc. The polymer coating is simple to apply, diffuses rapidly and non- toxic to the seed during germination. By encasing the seed with thin film of biodegradable polymer, the adherence of seed treatment to the seed is improves, ensures dust free handling, making treated seed both useful and environment friendly.

\section{Materials and Methods}

The experiment was conducted in the College farm, ANGRAU, Rajendranagar, Hyderabad during Kharif season, 2013. Freshly harvested seeds of soybean cv. JS-335 were collected from Agricultural Research Station (ARS), Adilabad, Andhra Pradesh and then treated with polymer@2 ml kg${ }^{-1}$ seed, thiram @3 g $\mathrm{kg}^{-1}$ seed, imidacloprid@2.5 ml kg-1 and Trichodermaviride@10 $\mathrm{g} \mathrm{kg}^{-1}$ seed. Seeds treated with polymer, thiram and imidacloprid were kept under the shade for 24 hours. Trichoderma viride was treated 1 (one) hour before sowing. The treated seeds along with untreated seeds (control) were used for field experiment to test the effect of different seed treatments. The experiment was laid out in Randomized Block Design (RBD) with four replications. Recommended package of practices were followed. The different seed treatment combinations used for the experiment of field studies is as follows:

T1: polymer coat alone

T2: polymer + thiram

T3: polymer + imidacloprid

T4: polymer + thiram + imidacloprid

T5: polymer + thiram + imidacloprid $+T$. viride

T6: untreated (control)
The data were collected on various characters. The field emergence index was recorded on alternate days starting from 4th day to 8th day after sowing in each treatment. The field emergence index was arrived as described by Baskin (1969)

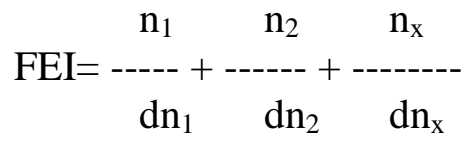

Where,

$\mathrm{n}_{1}=$ number of seedlings emerged on the first counting day

$\mathrm{n}_{\mathrm{x}}=$ number of seedlings emerged on the final counting day

$\mathrm{dn}_{1}=$ number of days from the date of sowing

$\mathrm{dn}_{\mathrm{x}}=$ number of days from the date of sowing to the final counting day

Disease incidence was recorded at three stages of crop growth period i.e., 25, 50 and 75 days after sowing and percentage incidence was calculated using the formula.

Number of diseased plants per plot

DI $(\%)=$------------------------------ x 100

Total number of plants per plot

(Healthy + diseased)

The plant height was measured from the base of the plant to the tip of the main shoot at maturity stage and expressed in centimetres (cm). Number of seeds per pod and number of pods per plant were taken in ten randomly selected plants and averaged to get the results. Yield of ten selected plants from each plot in each replication was recorded and averaged to get seed yield per plant. Yield obtained per plot was computed and extrapolated to get yield per hectare. A random sample of 100 seeds from each replication in all treatments 
were counted, weighed and expressed in grams for calculating 100 seed weight. The field data were analysed statistically as per randomized block design (RBD).

\section{Results and Discussion}

\section{Field emergence index}

Significant differences among the seed treatments were observed with respect to field emergence (Table1 and Fig. 1). This might be due to suppression of the activity of soil borne pathogens / fungi by seed treatment which improved seed germination, vigour, field emergence and establishment of healthy seedlings. Similar findings were confirmed earlier by Dubey et al., (2011) and Sunil Kumar (2004). Untreated seeds recorded minimum field emergence index $(82.30 \%)$ and significantly inferior to polymer, fungicide, insecticide and bioagent seed treatments. All the seed treatments have shown better performance in respect of field emergence as compared to untreated control $(82.30 \%)$. Among the seed treatments, polymer + thiram + imidacloprid $+T$. viride $\left(\mathrm{T}_{5}\right)(92.32 \%)$ followed by polymer + thiram + imidacloprid $\left(\mathrm{T}_{4}\right)(90.70 \%)$ recorded maximum field emergence index which were significantly superior to other treatments. In case of bioagent, T.viride showed higher field emergence with minimum activity of the pathogen which subsequently enhanced seed germination. It could be attributed due to production of not only antifungal compounds but also growth regulating chytinolytic enzymes like glucanases and proteases and thereby reducing the pathogenic activity. Similar observations were made by Krishna Murthy et al., in Pulses (2003). Improvement of seedling emergence in seed coating with polymer might be due to regulated rate of water uptake, reduced imbibition damage and improved germination per cent which is in accordance with the findings of Chachalis and Smith (2001).

Plant height (Table 1) and number of seed per pod (Table 2) were not differed significantly due to different seed treatments and their interaction at all the stages of crop growth.

\section{Disease incidence}

Disease incidence increased with the crop growth in all the seed treatments. Significant variation between seed treatments were observed in respect of disease incidence (Table 1 and Fig. 2). Disease incidence at 75 DAS (11.45\%) was significantly higher than 50 DAS (8.59\%) and 25 DAS (5.00\%). Disease incidence decreased over control with seed treatments at all stages of the crop growth. At 75 DAS polymer seed coating with thiram + imidacloprid $+T$. viride $(7.85 \%)$ and polymer coating with thiram $(8.75 \%)$ were found effective in reducing disease incidence followed by polymer coating with thiram + imidacloprid $(8.82 \%)$. Disease incidence in seed coated with polymer alone $(15.62 \%)$ at 75 DAS was also lower as compared to untreated seeds $(18.45 \%)$.

Untreated seeds recorded maximum incidence of diseases $(8.65 \%, 16.47 \%$ and $18.45 \%$ at 25 DAS, 50 DAS and 75 DAS respectively) at all the different stages of crop growth with respect to different seed treatments. Irrespective of the different seed treatments the following diseases viz., Macrophomina root rot (Macrophomina phaseolina), Alternaria leaf spot (Alternaria alternata), Anthracnose (Colletotrichum dematium) and Purple seed stain (Cercospora kikuchi), Soybean mosaic virus (SMV), Leaf crinkle virus (LCV), yellow mosaic virus (YMV) and peanut bud necrosis virus (PBNV) were observed. 
Seed treatments decrease the disease susceptibility of the seed during its germination in the soil. Fungicide treated seed controlled the external as well as internal seed borne pathogen and thus acts as a protective coating to prevent soil borne pathogens from seedling infection. Similar observations were reported by Hall and Xue (1995), Das and Dutta (1999) and Gaulart et al., (2000). Seeds pretreated with $T$. viride showed the reduction in incidence of seed-borne fungal pathogens compared to control (Zheng and Shetty (2000), Bharath et al., (2006), Mukhtar, (2008). Seed treatment with bioagent and fungicide produced better seedling stand than untreated control. This may be due to the suppression of seed borne pathogens during germination. A biological control agent that can function in combination with fungicide seed treatments suppresses seedling disease and thus controls the seedling disease. Similar results were reported by Howell et al., (1997).

Table.1 Effect of seed treatments on field emergence index, plant height $(\mathrm{cm})$ and disease incidence at different stages $(\%)$

\begin{tabular}{|c|c|c|c|c|c|}
\hline Treatment & Field emergence & Plant height & \multicolumn{3}{|c|}{ Disease incidence at different stage (\%) } \\
\cline { 4 - 6 } & index $(\mathbf{\%})$ & $(\mathbf{c m})$ & $\mathbf{2 5}$ days & $\mathbf{5 0}$ days & $\mathbf{7 5}$ days \\
\hline $\mathrm{T}_{1}$ & 85.12 & 33.88 & 6.49 & 12.10 & 15.63 \\
\hline $\mathrm{T}_{2}$ & 90.32 & 35.65 & 3.53 & 5.83 & 8.75 \\
\hline $\mathrm{T}_{3}$ & 91.02 & 34.95 & 3.83 & 5.88 & 9.20 \\
\hline $\mathrm{T}_{4}$ & 90.70 & 35.28 & 3.95 & 5.93 & 8.83 \\
\hline $\mathrm{T}_{5}$ & 92.32 & 35.55 & 3.60 & 5.38 & 7.85 \\
\hline $\mathrm{T}_{6}$ & 82.30 & 34.13 & 8.65 & 16.46 & 18.45 \\
\hline Mean & 88.63 & 10.24 & 5.01 & 8.60 & 11.45 \\
\hline S.E $\mathrm{m}$ & 0.15 & 0.52 & 0.15 & 0.15 & 0.19 \\
\hline C.D $(5 \%)$ & 0.48 & NS & 0.46 & 0.45 & 0.60 \\
\hline
\end{tabular}

Table.2 Effect of seed treatments on No. of pods per plant, No. of seeds per pod, Seed yield per plant (g) and Yield per ha (q)

\begin{tabular}{|c|c|c|c|c|c|}
\hline Treatment & $\begin{array}{c}100 \text { seed } \\
\text { weight }(\mathrm{g})\end{array}$ & $\begin{array}{c}\text { No. of pods } \\
\text { plant }^{-1}\end{array}$ & $\begin{array}{c}\text { No. of } \\
\text { seeds pod }^{-1}\end{array}$ & $\begin{array}{l}\text { Seed yield } \\
\text { plant }^{-1}(\mathrm{~g})\end{array}$ & $\begin{array}{c}\text { Yield ha }^{-1} \\
\text { (q) }\end{array}$ \\
\hline $\mathrm{T}_{1}$ & 11.25 & 60 & 3 & 9.92 & 14.88 \\
\hline $\mathrm{T}_{2}$ & 11.93 & 64 & 2 & 11.76 & 17.63 \\
\hline $\mathrm{T}_{3}$ & 11.91 & 62 & 3 & 10.96 & 16.44 \\
\hline $\mathrm{T}_{4}$ & 12.25 & 62 & 3 & 11.64 & 17.78 \\
\hline $\mathrm{T}_{5}$ & 12.50 & 66 & 3 & 12.27 & 18.40 \\
\hline $\mathrm{T}_{6}$ & 11.31 & 60 & 2 & 8.79 & 13.20 \\
\hline Mean & 11.86 & 62 & 3 & 10.89 & 16.39 \\
\hline S.E m & 0.195 & 1.12 & 0.05 & 0.22 & 0.31 \\
\hline C.D $(5 \%)$ & 0.59 & 3.40 & N.S & 0.68 & 0.93 \\
\hline
\end{tabular}


Fig.1 Effect of seed treatment on field emergence index in soybean

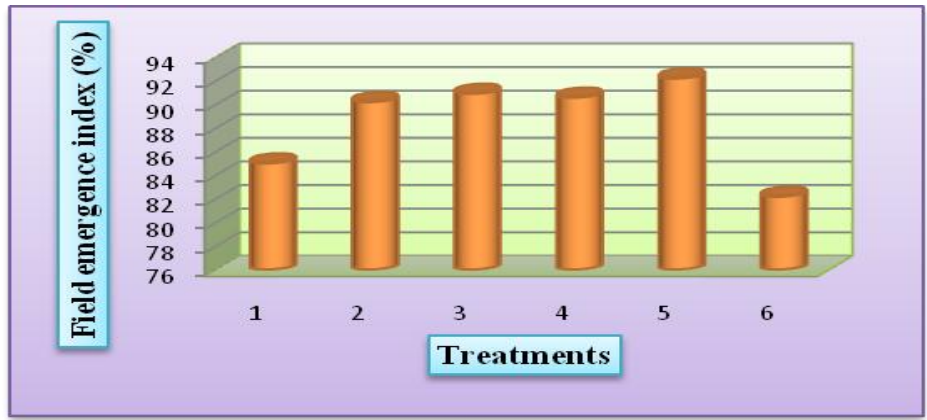

Fig.2 Effect of seed treatment on disease incidence (\%) at different crop stages in soybean

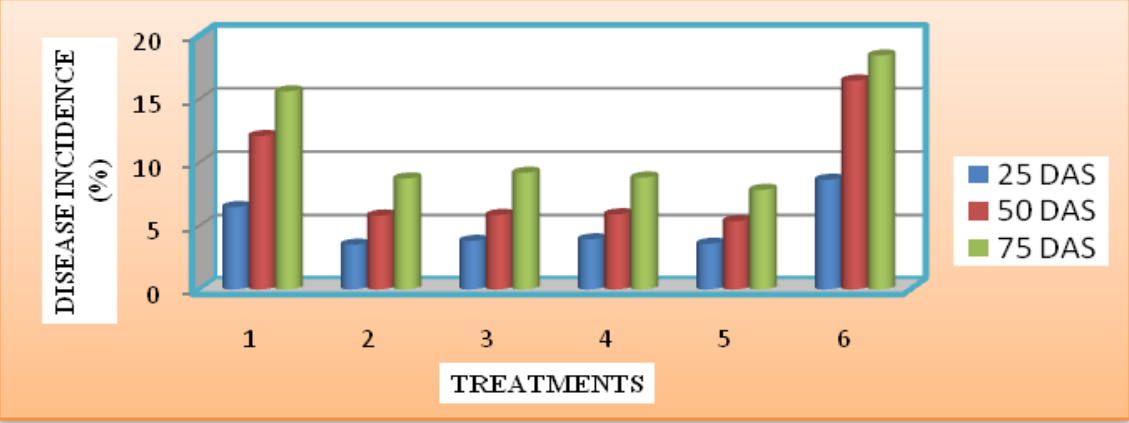

Fig.3 Effect of seed treatment on seed yield per plant $(\mathrm{g})$ in soybean

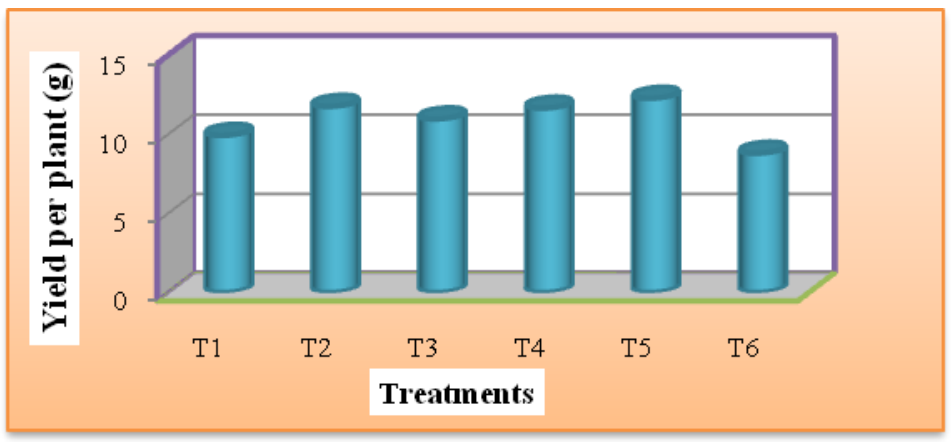

Fig.4 Effect of seed treatment on yield per hectare (q) in soybean

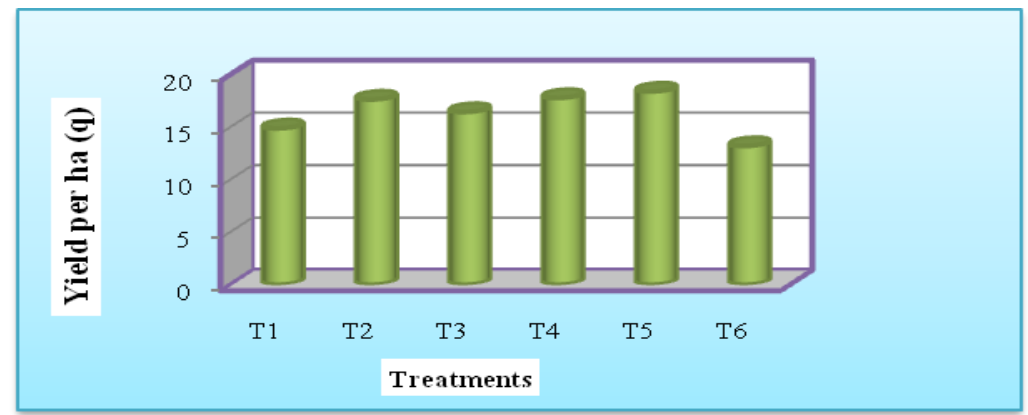




\section{Number of pods per plant}

A significant variation in number of pods per plant among the different seed treatments was observed (Table 2). Among the treatments, $\mathrm{T}_{5}$ (polymer + thiram + imidacloprid $+T$. viride $)$ recorded significantly high number of pods per plant (66) followed by $\mathrm{T}_{2}$ (polymer + thiram) (64) over control. Polymer coated seeds with imidacloprid $\left(\mathrm{T}_{3}\right)(62)$ and thiram + imidacloprid $\left(\mathrm{T}_{4}\right)$ (62) were found on par with each other however, recorded more number of pods per plant over control (60). Number of pods per plant was high in seed treatments with fungicides, insecticides and bioagents as compared with untreated seeds. The increase in number of pods may be due to the more number of branches per plant, decreased flower drop and increased pod setting, nutrient mobilization, nutrient uptake, release of plant growth promoting substances by microbial inoculants and antagonistic activity against pathogens. Similar response due to seed treatment was observed by Tripathi and Singh (1991) and Kanti et al., (2013).

\section{Hundred seed weight}

Hundred seed weight significantly differed in seed treatments (Table 2). Polymer coated seed with thiram + imidacloprid $+T$. viride $\left(\mathrm{T}_{5}\right)$ recorded highest 100 seed weight $(12.50$ g) followed by polymer coated seeds with thiram + imidacloprid (12.24 g) which were significantly superior to other treatments. Polymer coated seeds with thiram (11.93 g) and imidacloprid (11.90 g) were also recorded high 100 seed weight as compared to untreated seeds $(11.31 \mathrm{~g})$. The differences in 100 seed weight might be due to the infestation of the insects, which will feed both internally and externally and also due to activity of the fungi. The increase in seed weight in treated seeds may be due to the inhibition of activity of pathogen resulted in more dry matter production and availability of photosynthates for sink which ultimately resulted in more seed weight. Similar findings were observed by Tripathi and Singh (1991), Anuja et al., (2000), Taywede et al., (2002) and Rezende et al., (2003).

\section{Seed yield plant $^{-1}(\mathrm{~g})$}

Seed treatments gave significantly higher seed yield over control $(8.79 \mathrm{~g})$ and (Table 2 and Fig. 3). Polymer with thiram + imidacloprid + T. viride $\left(\mathrm{T}_{5}\right)$ recorded the maximum seed yield per plant (12.26 g) followed by polymer with thiram $\left(\mathrm{T}_{2}\right)$ (11.75 g), polymer coated seeds with thiram + imidacloprid $\left(\mathrm{T}_{4}\right)(11.64$ g) and polymer with imidacloprid (10.96 g). The seeds coated with polymer alone was also found effective in increasing the seed yield and recorded more seed yield per plant (9.92 g) over untreated seeds $(8.79 \mathrm{~g})$. The increase in per plant yield mass may be attributed to good plant growth and development of the seeds promoted by polymer coating, fungicide and insecticide. Similar results were also reprted by Chikkanna et al., (2000), Shakuntala et al., (2010) and Vinodkumar et al., (2013). The appreciable increase in yield may be attributed to extensive root development and better uptake translocation of nitrogen and phosphorous towards above ground parts. Plant growth promoting substances secreted by microorganism helped in various metabolic activities and reduction of pathogens and in the proliferation of benefical organisms in the rhizosphere which led to higher number of branches and number of pods per plant which in turn led to higher seed yield per plant. Similar findings due to seed treatments were observed by Singh and Agarwal (1988), Kawale et al., (1989), Tripathi and Singh (1991) and Kanti et al., (2013) in soybean.

\section{Yield hectare $^{-1}(q)$}

There was a significant improvement in seed yield per hectare in the seed treatments of 
polymer + thiram + imidacloprid $+T$. viride $\left(\mathrm{T}_{5}\right)(18.40 \mathrm{q})$ followed by polymer + thiram + imidacloprid) $\left(\mathrm{T}_{4}\right)$ (17.78 q), polymer + thiram $\left(\mathrm{T}_{2}\right)(17.63 \mathrm{q})$, polymer + imidacloprid $\left(\mathrm{T}_{3}\right)(16.44 \mathrm{q})$ and polymer coat alone $\left(\mathrm{T}_{1}\right)$ (14.88 q) as compared to untreated control (13.20 q) (Table 2 and Fig. 4). The improvement in yield per hectare over control were 5.2, 4.58, 3.24, 4.43, $1.68 \mathrm{q}$ with seed treatments of polymer + thiram + imidacloprid $+T$. viride, polymer + thiram + imidacloprid, polymer + thiram, polymer + imidacloprid and polymer (polymer@2 ml $\mathrm{kg}^{-1}$, thiram@2 $\mathrm{g} \mathrm{kg}^{-1}$, imidacloprid 2.5ml $\mathrm{kg}^{-1}, T$. viride @ $10 \mathrm{~g} \mathrm{~kg}^{-1}$ of seed). The increased yield was attributed to better plant establishment with suppression of seed borne diseases. Similar findings were observed by Rajeswari and Meena Kumari in soybean (2009). The probable reason for such findings was due to more number of pods per plant and seed yield per plant which in turn led to higher yield per hectare. Similar results were observe by Kawale et al., (1989), Tripathi and Singh (1991), Chikkanna et al., (2000), Shakuntala et al., (2010) and Vinodkumar et al., (2013) and Kanti et al., (2013).

\section{References}

Anuja, G., and Aneja, K.R. 2000. Field efficacy of seed dressing chemicals on seedling emergence, seed yield and seed weight in soybean. Seed Research. 28: 54-58.

Baskin, C. C., 1969. GADA and seedling measurements as tests for seed quality. Proceedings of Seedsman Short Course, Mississippi State University, pp.59-64.

Chachalis, D., and Smith, M. L. 2001. Hydrophobic polymer application reduces imbibitions rate and partially improves germination or emergence of soybean seedlings. Seed Scence and Technology. 29(1): 91-98.

Chikkanna, C.S., Timmegouda and Ramesh,
R. 2000. Hydrophilic polymer seed treatment on seed quality and yield in fingermillet, cowpea and groundnut. Seeds and Farms. 85: 39-45.

Kanti, V.M., Bala, N., Rai, P.K., Lavanya, G.R and Suresh Babu. 2013. Combined and Individual action of bioagents and fungicides on seed yield of Soybean (Glycine max L. Merrill). New York Science Journa.l. 6(4): 32-35.

Kawale, B.A., Kurundkar, B. P and Thombre, P. A. 1989. Effect of fungicide and insecticide, weedicides on emergence and yield of soybean (Glycine max (L.) Merril). Journal of Oil Seed Research. 6: 357-359.

Krishna Murthy, Niranjana, S. R and Shetty, H. S. 2003. Effects of chemical fungicides and biological agent on seed quality improvement in pulses. Seed Research. 31(1): 121-124.

Mucke, J.D., 1987. The regulation of water transport in pelleted sugar beet seed. Journal of Agronomy and Crop Science. 161:79-83.

Rajeswari, B., and Meena Kumari, K.V.S. 2009. Bioagents and fungicides for the management of seed and seedling diseases of soybean. Indian Journal of Plant Protection. 37 (2): 121-131.

Rezende, P.M., Machado, J.C., Gris, C.F., Gomes, L.L., Botrel, E.P.C and Machado, J. 2003. Effect of dry soil sowing and seeds treatment on emergence, yields grains and characteristics of soybean. Cienca.e. Agrotecnologia. 27 (1): 76-83.

Shakuntala, N.M., Vyakaranahal, B.S., Shankergoud, I. Deshpande, V. K., Pujari, B.T and Nadaf, H. L. 2010. Effect of seed polymer coating on growth and yield of sunflower hybrid RSFH-130. Karnataka Journal of Agricultural Sciences. 23 (5): 708-711.

Taywade, A.S., Potolukhe, S.R., Shivankar, R.S., Sonone, J.S and Naphade R.S. 
2002. Effect of seed dressing chemicals and Rhizobium inoculation on the yield of soybean [Glycine max. (L) merill]. Legumes Research. 25 (4): 297-298.

Tripathi, D.P., and Singh, B.R. 1991. Mycoflora of soybean seed and their control. Madras Agricultural Journal. 78 (1-4); 130-132.
Vinodkumar, S.B., Vyakaranahal, B.S., Dhananjaya, P., Hipparagi, Y and Asha A.M. 2013. Effect of seed polymer coating on field performance and quality of pigeonpea (Cajanus cajan (L.) Mill sp). Environment and Ecology. 31 (1): 43-46.

\section{How to cite this article:}

Bony, R.K., B. Rajeswari, K. Jhansi and Keshavulu, K. 2017. Effect of Seed Coating on Field Performance in Soybean (Glycine max. L). Int.J.Curr.Microbiol.App.Sci. 6(11): 4304-4311. doi: https://doi.org/10.20546/ijcmas.2017.611.506 